\title{
Pengaruh Parenting Class Kesehatan Reproduksi Remaja terhadap Pengetahuan dan Sikap Orangtua dalam Pencegahan Kehamilan Remaja
}

\author{
The Influence of Parenting Class on Reproductive Health toward Knowledge and Attitude of \\ Parents in Prevention of Teens Pregnancy
}

\author{
Fitriani Mediastuti, Era Revika \\ Sekolah Tinggi Ilmu Kesehatan AKBIDYO Yogyakarta
}

\begin{abstract}
ABSTRAK
Kehamilan pada remaja merupakan salah satu masalah kesehatan yang berkelanjutan. Salah satu faktor eksternal yang sangat berpengaruh terhadap perilaku seksual remaja adalah keluarga. Interaksi dengan orangtua sangat mempengaruhi perkembangan individu remaja. Keterlibatan orang tua dan komunikasi orangtua dengan anak dapat mempromosikan perilaku sehat, sehingga mencegah remaja untuk hamil. Penelitian ini untuk mengetahui efektifitas model parenting class kesehatan reproduksi remaja terhadap pengetahuan dan sikap orangtua dalam pencegahan kehamilan remaja.Jenis penelitian ini merupakan penelitian quasi experimental dengan rancangan pretest-posttest control design. Lokasi penelitian di Wilayah Desa A dan B Kecamatan Sewon, Kabupaten Bantul. Sampel dalam penelitian ini dipilih dengan purposive sampling. Analisis data dilakukan dengan paired t-test dan menggunakan bantuan software stata. Hasil penelitian menunjukkan bahwa variabel pengetahuan pada kelompok intervensi memiliki perbedaan yang signifikan ( $p$ value $=0,01)$; sedangkan pada kelompok kontrol di antara pretest dan posttest terdapat perbedaan yang tidak signifikan ( $p$ value $=0,87$ ). Variabel sikap pada kelompok intervensi terdapat perbedaan yang signifikan ( $p$ value $=0,01)$; sedangkan pada kelompok kontrol di antara pretest dan posttest terdapat perbedaan yang tidak signifikan ( $p$ value $=0,97)$. Model $p a r e n t i n g$ class kesehatan reproduksi remaja efektif terhadap pengetahuan dan sikap orangtua dalam pencegahan kehamilan remaja.
\end{abstract}

Kata Kunci: Kehamilan remaja, parenting class, pengetahuan, sikap

\begin{abstract}
Pregnancy among teenagers is one of the persisting health issues. One of the most powerful external factors in teenagers' sexual behavior is family. Interaction with parents greatly influences the development of adolescent individuals. Parental involvement and parent-child communication can promote healthy behaviors, thus preventing teenagers from pregnancy. This research aimed to determine the effectiveness of the parenting class model of adolescent reproduction health toward parent knowledge and attitude in the prevention of teenage pregnancy. This research was a quasi-experimental study with pretest-posttest control design. The research was located at Village A and Village B of Sewon District, Bantul Regency. The respondents were chosen by purposive sampling. Data analysis was done using paired t-test and Stata software. The results showed that the knowledge variable in the intervention group had significant differences $(p$-value $=0.01)$; whereas that in the control group showed no significant difference between pretest and posttest ( $p$-value $=0.87)$. Attitude variable in the intervention group showed a significant difference ( $p$-value $=0.01)$; whereas that in the control group showed no significant difference between pretest and posttest ( $p$-value $=0,97)$. The parenting class model of adolescent reproduction health is effective in supporting parents' knowledge and attitude in preventing teenage pregnancy.
\end{abstract}

Keywords: Attitude, knowledge, parenting class, teens pregnancy

Korespondensi: Fitriani Mediastuti. Sekolah Tinggi Ilmu Kesehatan AKBIDYO Yogyakarta, Jl. Parangtritis KM.6, Sewon, Panggungharjo, Bantul, Daerah Istimewa Yogyakarta 55188 Tel. (0274)371345/08179415400Email:fi_medi@yahoo.com

DOI: http://dx.doi.org/10.21776/ub.jkb.2019.030.03.11 


\section{PENDAHULUAN}

Usia remaja merupakan usia yang sangat rentan. Interaksi dengan keluarga, masyarakat, dan komunitas sangat mempengaruhi perkembangan individu untuk menciptakan kondisi kesehatan baik positif maupun negatif. Usia remaja merupakan saat yang paling ideal untuk membuat keputusan seksual dan reproduksi yang aman (1). Hal tersebut dikarenakan pada usia remaja (1019) tahun terjadi perubahan biologis, kognitif, emosional, dan sosial (2). Periode tersebut terjadi perkembangan sensitif kedua dan pertumbuhan cepat yang berfokus pada kematangan otak individual yang menyebabkan rangkaian perilaku dan kapasitas baru. Perkembangan ini memicu atau memungkinkan masalah yang berhubungan dengan populasi, transisi dalam keluarga, teman, dan perilaku kesehatan. Pada masa ini terjadi perbedaan antara individu dalam hal masa transisi lintasan masa kecil menuju kesehatan dan kesejahteraan (3).

Selama tahun 2015, Dinas Kesehatan DIY mencatat ada 1.078 remaja usia sekolah di Yogyakarta yang melakukan persalinan dan 976 (90\%) di antaranya hamil di luar pernikahan. Angka tersebut merata di seluruh kabupaten. Data PKBI tahun 2015 menyebutkan jumlah pelajar hamil di luar nikah terbanyak adalah Kabupaten Bantul yakni 276 kasus, kemudian Kota Yogyakarta 228 kasus, Kabupaten Sleman 219 kasus, Kabupaten Gunung Kidul 148 kasus, dan Kabupaten Kulon Progo 105 kasus. Kementerian Agama Kabupaten Bantul menyebutkan bahwa data pernikahan dini dengan latar belakang kehamilan remaja yang terjadi pada tahun 2015 di Kabupaten Bantul tertinggi berada di Kecamatan Sewon sebanyak 19 orang. Menurut Pengadilan Agama, hampir semua pengajuan dispensasi nikah karena alasan kehamilan.

Salah satu faktor eksternal yang sangat berpengaruh terhadap perkembangan remaja adalah lingkungan keluarga. Peran orang tua sangat dibutuhkan dalam pemantauan perkembangan remaja. Orang tua memainkan peran penting dalam kesehatan anak-anak mereka, termasuk keputusan yang terkait dengan perilaku seksual. Sebuah penelitian menunjukkan intervensi komunikasi orangtua dan anak mampu mengurangi risiko seksual untuk remaja. Intervensi tersebut juga dapat membantu mengurangi kesenjangan kesehatan terkait HIV/IMS dan meningkatkan kesehatan seksual (4).

Beberapa penelitian terkait upaya pencegahan perilaku berisiko pada remaja, khususnya kehamilan remaja telah dilakukan. Meskipun demikian penelitian-tersebut tersebut mayoritas masih difokuskan di sekolah karena sekolah memang belum terbuka untuk masalah kesehatan seksual sehingga tidak melakukan intervensi. Penelitian Kwon dan Wickrama menyebutkan bahwa pola asuh merupakan salah satu faktor yang secara tidak langsung berpengaruh terhadap perilaku berisiko pada remaja (5). Penelitian O'Donnell dan Fuxman menyebutkan bahwa intervensi pengasuhan yang efektif dapat meningkatkan pendidikan kesehatan dan seksualitas berbasis sekolah dan membantu orang tua Latino mendukung anak-anak mereka pada masa remaja awal (6). Berbeda dengan penelitian tersebut, penelitian ini menfokuskan model parenting class pada orang tua untuk meningkatkan pengetahuan dan keterampilan sikap orang tua dalam upaya pencegahan kehamilan remaja berbasis masyarakat.
Pemerintah melalui BKKBN telah mengupayakan program pencegahan kehamilan remaja, di antaranya melalui program generasi berencana dengan wadah Pusat Informasi dan Konsultasi Remaja/Pusat Informasi dan Konseling Mahasiswa (PIKR/PIKM). Selain itu juga adanya program Bina Keluarga Remaja (BKR), yang bertujuan dalam upaya meningkatkan pengetahuan, sikap dan ketrampilan orang tua dan anggota keluarga lain dalam membina tumbuh kembang anak dan remaja secara seimbang melalui komunikasi efektif antara orang tua dan anak remaja. Penelitian ini mencoba menggali keefektifan model parenting class yang melibatkan anggota PIKM Laras hati terhadap pengetahuan dan sikap orang tua dalam upaya pencegahan kehamilan remaja.

\section{METODE}

Jenis penelitian ini merupakan penelitian quasi experimental dengan rancangan pretest-posttest control design. Intervensi yang diberikan adalah pemberian materi kelas parenting dalam upaya pencegahan kehamilan remaja pada orang tua oleh pendidik sebaya dan konselor terlatih dari Pusat Informasi dan Konseling Mahasiswa (PIKM) Larashati Akademi Kebidanan Yogyakarta. Penelitian ini dilakukan di wilayah Kecamatan Sewon, Kabupaten Bantul yang merupakan wilayah dengan kejadian kasus pernikahan dini dengan latar belakang kasus kehamilan remaja yang tertinggi di DIY. Kelompok intervensi dilakukan di wilayah Desa A dan kelompok kontrol dilakukan di wilayah Desa B dengan karakteristik daerah yang hampir sama. Waktu pelaksanaan pretest dan dilanjutkan pemberian materi dilakukan pada hari Sabtu tanggal 11 Agustus 2017. Posttest dilakukan satu bulan kemudian pada hari Senin tanggal 11 September 2017.

Intervensi parenting class merupakan tindakan yang dirancang untuk mendukung orangtua serta meningkatkan kapasitas dan kepercayaan diri orangtua dalam membesarkan anak-anak yang sehat. Materi yang diberikan dalam parenting class adalah materi seksualitas dan pencegahan kehamilan remaja serta teknik komunikasi dan konseling dengan remaja dengan metode kuliah yang dilanjutkan dengan role play dan diskusi. Penyampaian materi dibagi menjadi dua sesi dan dilakukan dalam satu hari. Sesi pertama tentang seksualitas dan pencegahan kehamilan remaja kemudian sesi kedua adalah teknik komunikasi dan konseling dengan remaja. Pemateri dari tim PIKM Larashati yang sudah terlatih menjadi konselor dan pendidik sebaya. Pada kelompok intervensi, selama proses intervensi, orang tua tidak mendapatkan intervensi lain demikian juga pada kelompok kontrol selama proses penelitian tidak memperoleh intervensi apapun. Meskipun demikian ada beberapa faktor yang tidak bisa dikendalikan pada masingmasing individu, yaitu kegiatan yang dilakukan di luar program ini, misalnya mencari informasi sendiri melalui internet. Untuk memenuhi aspek etis, setelah penelitian selesai, pada kelompok kontrol diberikan materi parenting class.

Sampel dalam penelitian ini dipilih dengan purposive sampling. Kriteria inklusi adalah sebagai berikut: memiliki anak usia remaja (10-19 tahun), tinggal serumah dengan anaknya dan bersedia berpartisipasi dalam proses penelitian. Dalam penelitian ini tidak membedakan jenis kelamin remaja tersebut karena pencegahan kehamilan remaja wajib diketahui baik pada remaja perempuan 
maupun laki-laki. Kajian menunjukkan bahwa remaja lakilaki umumnya menekan pasangan wanita dalam berhubungan seks dengan berbohong atau ancaman fisik sedangkan perempuan cenderung menyerah dan membiarkan seks terjadi (7).

Penentuan besar sampling dilakukan dengan mengacu pada teori rule of thumb yaitu sampel minimal 30 responden penelitian pada tiap kelompok. Lima responden kelompok intervensi tidak disertakan karena tidak mengikuti secara lengkap sebagai syarat kelompok intervensi. Oleh karena itu, jumlah responden kelompok kontrol dan kelompok intervensi masing-masing 30 responden dan 25 responden. Latar belakang karakteristik responden yang dilihat meliputi: usia, pendidikan terakhir, pekerjaan, pendidikan terakhir suami/istri, pekerjaan suami/istri, pengalaman mendapatkan informasi kesehatan reproduksi dan asal informasi yang sudah mendapatkan informasi kesehatan reproduksi.

Pengetahuan orang tua tentang upaya pencegahan kehamilan remaja diukur dengan kuesioner yang difokuskan pada pertanyaan tentang sistem reproduksi manusia dan kehamilan remaja serta dampaknya. Pengukuran nilai sikap dilakukan dengan memberikan 26 pernyataan pada orang tua. Isi dari pernyataan sikap yang diajukan adalah sikap orang tua terhadap remaja dalam upaya menjaga agar putra putrinya tidak mengalami kehamilan remaja dan sikap dalam membangun komunikasi yang kondusif pada orang tua dengan anak remaja. Analisis data menggunakan bantuan komputerisasi program Stata 12 dengan Paired sample ttest karena untuk menguji efektifitas suatu perlakuan terhadap suatu besaran variabel yang ingin ditentukan.

\section{HASIL}

Penelitian ini melibatkan orang tua yang memiliki anak remaja usia 10-19 tahun. Berdasarkan data pada Tabel 1 terlihat bahwa responden pada kelompok kontrol maupun intervensi memiliki karakteristik yang hampir sama. Responden yang hadir untuk mengikuti kelas parenting ini semuanya adalah ibu (100\%) dengan mayoritas berpendidikan SMA/SMK dan sebagai ibu bekerja. Mayoritas suami dari responden juga memiliki pendidikan terakhir SMA/SMK dan bekerja pada bidang nonformal diantaranya wiraswasta, tani, buruh. Mayoritas responden juga berasal dari keluarga dengan status keluarga inti, yang artinya tinggal bersama suami dan anak kandung. Responden sebagian besar juga belum pernah mendapatkan materi kesehatan reproduksi untuk kelompok intervensi dan untuk kelompok kontrol mayoritas sudah mendapatkan. Sumber informasi yang diperoleh mayoritas dari guru (ketika mereka dulu sekolah) dan TV/Radio/Majalah/Koran/Internet.

Tabel 1. Latar belakang responden

\begin{tabular}{|c|c|c|c|c|c|}
\hline \multirow[b]{2}{*}{ No } & \multirow[b]{2}{*}{ Variabel } & \multirow{2}{*}{$\begin{array}{c}\text { Kelompok } \\
\text { intervensi } \\
(n=25)\end{array}$} & \multicolumn{3}{|c|}{ Kelompok } \\
\hline & & & (\%) & $\begin{array}{c}\text { kontrol } \\
(n=30)\end{array}$ & (\%) \\
\hline \multirow[t]{3}{*}{1} & Jenis Kelamin & & & & \\
\hline & Perempuan & 25 & 100 & 30 & 100 \\
\hline & Laki-laki & 0 & & 0 & \\
\hline \multirow[t]{3}{*}{2} & Usia & & & & \\
\hline & $20-35$ & 2 & 8 & 2 & 6,7 \\
\hline & $>36$ & 23 & 92 & 28 & 93,3 \\
\hline
\end{tabular}

Tabel 1. Latar belakang responden (Lanjutan)

\begin{tabular}{|c|c|c|c|c|c|}
\hline \multirow[b]{2}{*}{ No } & \multirow[b]{2}{*}{ Variabel } & \multirow{2}{*}{$\begin{array}{c}\text { Kelompok } \\
\text { intervensi } \\
(n=25)\end{array}$} & \multicolumn{3}{|c|}{ Kelompok } \\
\hline & & & i (\%) & $\begin{array}{l}\text { kontrol } \\
(n=30)\end{array}$ & (\%) \\
\hline \multirow[t]{6}{*}{3} & Pendidikan & & & & \\
\hline & Tidak Sekolah & & & 1 & 3,3 \\
\hline & SD & 5 & 20 & 13 & 43,3 \\
\hline & SMP & 4 & 16 & 2 & 6,7 \\
\hline & SMA/SMK & 13 & 52 & 12 & 40 \\
\hline & PT & 3 & 12 & 2 & 6,7 \\
\hline \multirow[t]{4}{*}{4} & Pekerjaan & & & & \\
\hline & $\begin{array}{l}\text { Informal (wiraswasta, } \\
\text { buruh, pedagang) }\end{array}$ & 14 & 56 & 15 & 50 \\
\hline & Formal (PNS, Karyawan Swasta) & 3 & 12 & 0 & 0 \\
\hline & Tidak bekerja & 8 & 32 & 15 & 50 \\
\hline \multirow[t]{5}{*}{5} & Pendidikan Suami/Istri & & & & \\
\hline & SD & 3 & 12 & 13 & 43,3 \\
\hline & SMP & 7 & 28 & 2 & 6,7 \\
\hline & SMA/SMK & 11 & 44 & 12 & 40 \\
\hline & PT & 4 & 16 & 3 & 10 \\
\hline \multirow[t]{3}{*}{6} & Pekerjaan Suami/Istri & & & & \\
\hline & $\begin{array}{l}\text { Bekerja (pedagang, wiraswasta, } \\
\text { buruh, tani) }\end{array}$ & a, 22 & 88 & 29 & 96,7 \\
\hline & Tidak Bekerja & 3 & 12 & 1 & 3,3 \\
\hline \multirow[t]{3}{*}{7} & $\begin{array}{l}\text { Informasi mendapatkan materi } \\
\text { kesehatan reproduksi }\end{array}$ & & & & \\
\hline & Sudah & 8 & 32 & 19 & 63,3 \\
\hline & Belum & 17 & 68 & 11 & 36,7 \\
\hline \multirow[t]{5}{*}{8} & $\begin{array}{l}\text { Asal Informasi mendapatkan } \\
\text { materi }\end{array}$ & & & & \\
\hline & TV/Radio/Majalah/Koran/Internet & 1 & 12,5 & 9 & 47,4 \\
\hline & Guru & 6 & 75 & 5 & 26,3 \\
\hline & Teman & 1 & 12,5 & 1 & 5,3 \\
\hline & BKKBN, PKBI & & & 4 & 21 \\
\hline \multirow[t]{3}{*}{9} & Status Keluarga & & & & \\
\hline & Inti & 22 & 88 & 30 & 100 \\
\hline & Selain inti & 3 & 12 & 0 & 0 \\
\hline
\end{tabular}

Hasil (Tabel 2) menunjukkan bahwa pada kelompok intervensi terjadi peningkatan pengetahuan dan sikap yang signifikan secara statistik, sedangkan pada kelompok kontrol tidak ditemukan perbaikan signifikan. Pada kelompok intervensi terjadi peningkatan nilai pengetahuan sebesar $(2,68)$ dan sikap $(3,24)$, sedangkan pada kelompok kontrol nyaris tidak ada perubahan pengetahuan $(0,10)$ dan sikap $(0,02)$.

Tabel 2. Perubahan rerata tingkat pengetahuan sesudah intervensi pada dua kelompok

\begin{tabular}{llrr}
\hline Kelompok & & Pengetahuan & Sikap \\
\hline Intervensi & Pre & $19 \pm 3,45$ & $19,06 \pm 2,89$ \\
& Post & $21,68 \pm 3,41$ & $19,16 \pm 3,62$ \\
& Rerata beda & 2,68 & 0,10 \\
& $\mathrm{Cl}, \mathrm{p}$ & $1,20 \mathrm{~s} / \mathrm{d} \mathrm{4,15}$ & $1,14 \mathrm{~s} / \mathrm{d} 1,34$ \\
Kontrol & Pre & 0,01 & 0,87 \\
& Post & $87,84 \pm 8,3$ & $83,76 \pm 6,27$ \\
& Rerata beda & $91,08 \pm 6,37$ & $83,74 \pm 8,57$ \\
& Cl, p & 3,24 & 0,02 \\
& & $0,60 \mathrm{~s} / \mathrm{d} \mathrm{5,87}$ & $2,62 \mathrm{~s} / \mathrm{d} 2,69$ \\
& 0,01 & 0,97 \\
\hline
\end{tabular}

\section{DISKUSI}

Orangtua memainkan peran penting dalam pertumbuhan, perkembangan dan sosialisasi seksual anak-anak mereka. 
Keterlibatan orangtua melalui komunikasi seksual orangtua-anak yaitu dalam menyajikan pendidikan tentang seks dan kesehatan reproduksi kepada kaum muda sangat penting. Hasil penelitian menyatakan bahwa mayoritas responden berasal dari keluarga inti yang artinya anak tinggal bersama ayah dan ibu kandung, namun masih banyak orangtua yang belum pernah mendapatkan materi kesehatan reproduksi dan memberikan informasi kesehatan reproduksi remaja ke anak.

Orang tua merupakan pendidik seks yang paling dominan. Dalam komunikasi tentang seksual orang tua dengan anak, orangtua mentransmisikan nilai seksual, kepercayaan, informasi dan harapan kepada anak-anak mereka dengan tujuan mempengaruhi perilaku seksual, sikap, dan pengambilan keputusan anak-anak mereka. Oleh karena itu, komunikasi seksual orang tua untuk memberdayakan kaum muda memiliki banyak tantangan yang tidak dapat diremehkan (8). Komunikasi positif antara orang tua dan anak sangat membantu kaum muda untuk membangun nilai individu dan mengambil keputusan yang sehat (9). Sebuah kajian menemukan bahwa remaja yang memiliki hubungan yang baik dengan orang tua dan keluarga lebih mungkin untuk menunda hubungan seksual pranikah. Remaja yang mengatakan bahwa keluarga yang harmonis dan saling perhatian juga dapat menjauhkan diri dari ganja dan tekanan emosional yang tidak baik dari teman sebayanya. Ketika orang tua dan remaja memiliki komunikasi yang baik, seiring dengan perkembangan yang tepat, penelitian menunjukkan bahwa kaum muda lebih percaya diri dan memiliki harga diri. Penelitian tersebut juga menyebutkan orang muda yang melaporkan bahwa mereka merasa tidak adanya kehati-hatian, cinta, atau perhatian orang tua juga lebih cenderung melaporkan tekanan emosional, rendahnya harga diri, masalah sekolah, penggunaan narkoba, dan risiko seksual (9).

Secara statistik, hasil penelitian menunjukkan bahwa kelas parenting berpengaruh terhadap pengetahuan dan sikap orang tua dalam upaya pencegahan kehamilan remaja. Selama mengikuti kelas tersebut, orang tua menunjukkan sikap yang sangat antusias dan banyak bertanya serta sharing dari pengalaman yang selama ini dialaminya dalam mendidik anak remajanya. Banyak orangtua yang ternyata belum terbuka dengan anak untuk melakukan diskusi kesehatan reproduksi. Oleh karenanya, kelas parenting tersebut sangat membantu informasi orang tua yang diberikan ke anak remaja dalam memberikan berkomunikasi dengan anak. Penelitian Beckett et al. menyatakan bahwa dokter spesialis anak mendorong orang tua untuk mendidik remaja mereka tentang seksualitas mulai di awal kehidupan. Banyak remaja yang menyampaikan bahwa hanya sedikit dan bahkan tidak ada komunikasi sama sekali tentang seksualitas dengan orang tua mereka. Dalam penelitian tersebut disampaikan pula perlunya informasi untuk orang tua terkait cara menangani kesehatan seksual pada remaja dan waktu yang tepat dalam memberikan edukasi tersebut ke anak (10).

Selama masa remaja, hubungan orangtua-anak mengalami reorganisasi yang signifikan untuk merespons perubahan kebutuhan dan tantangan yang disajikan pada masa transisi anak. Masa remaja juga bisa mewakili masa konflik interpersonal karena kesulitan dalam menangani transisi tidak hanya dari remaja tetapi juga dari orangtua.
Oleh karena itu, peningkatan otonomi pada masa remaja memaksa orang tua untuk menjadi lebih kreatif dalam memantau dan mengawasi anak-anak mereka (11).

Dalam kelas parenting ini, semua responden yang hadir adalah perempuan (ibu) meskipun sebenarnya yang diundang bukan ibu saja, tetapi salah satu orang tua (ayah atau ibu). Hal tersebut menunjukkan bahwa dalam urusan peningkatan pengetahuan untuk mendidik anak lebih diserahkan pada ibu, padahal peran ayah sangat dibutuhkan dalam membentuk karakter anak. Penelitian Manu et al., menunjukkan bahwa mayoritas orang tua di wilayah Brong Ahafo di Ghana melibatkan anak-anak mereka dalam pembicaraan terkait seks, namun sebagian besar percakapan terkonsentrasi pada beberapa topik seksual seperti pantangan, menstruasi HIV/AIDS, PMS dan pubertas. Ibu lebih banyak membicarakan masalah kesehatan seksual dan reproduksi dengan anak mereka daripada ayah (8). Strategi perlu dirancang untuk mendorong keterlibatan ayah dalam komunikasi seksual orangtua.

Pengetahuan dan sikap orangtua terkait dengan pencegahan kehamilan remaja sangat mempengaruhi perilaku anak dalam upaya pencegahan kehamilan remaja. Orangtua merupakan sumber informasi kesehatan yang penting bagi remaja, termasuk informasi kesehatan seksual (11). Sikap merupakan prediktor paling kuat terhadap niat dan selanjutnya akan membentuk perilaku seseorang (12). Kurangnya keterampilan mengasuh anak juga dapat berkontribusi pada hasil negatif bagi anak-anak dari orangtua remaja termasuk: tingkat kriminal yang meningkat pada masa remaja dan dewasa, prestasi sekolah yang lebih rendah dengan tingkat putus sekolah yang lebih tinggi daripada rata-rata, masalah kesehatan, pengangguran sebagai orang dewasa, dan kemungkinan yang lebih tinggi juga menjadi orangtua remaja (13).

Lingkungan dan keluarga akan mempengaruhi sikap seksual seseorang. Cara pandang keluarga, khususnya orangtua terhadap kehamilan pada remaja akan mempengaruhi sikap orangtua dalam upaya pencegahannya. Keluarga berfungsi dalam menjalankan fungsi afeksi yakni penerapan nilai moral dan keterbukaan komunikasi dapat membantu remaja untuk menyalurkan dorongan seksualnya sesuai dengan norma dan nilai yang berlaku. Sebuah penelitian menyebutkan bahwa orang tua lebih sering berkomunikasi dengan anak perempuan dan lebih cenderung menekankan konsekuensi negatif dari aktivitas seksual ketika mendiskusikan aktivitas seksual dengan anak perempuan dibandingkan dengan anak lakilaki (14). Hal ini juga sesuai dengan penelitian Caruthers et al. yang menyatakan bahwa hubungan orangtua dan anak dengan meningkatkan keterampilan komunikasi dan mendorong orangtua untuk menghabiskan waktu yang berkualitas dengan anak-anaknya akan mempengaruhi pencegahan perilaku seksual berisiko tinggi pada remaja (15).

Hasil penelitian menunjukkan bahwa program intervensi parenting class dalam upaya pencegahan kehamilan remaja memiliki pengaruh terhadap pengetahuan dan sikap orangtua. Strategi tersebut dapat membantu pemahaman yang lebih mendalam terkait hambatan orang tua dalam memberikan edukasi ke anak remaja. Penelitian Morawska et al. menyebutkan bahwa orangtua masih banyak yang belum memiliki keterampilan dan keyakinan yang berkaitan dengan topik atau masalah 
tertentu (seksualitas) dan penyampaian yang sesuai dengan anak-anak mereka (16). Hal tersebut sesuai dengan penelitian Sneed et al., yang menyebutkan bahwa orang tua dapat memainkan peran yang lebih penting daripada teman sebaya dalam mencegah niat perilaku remaja perempuan untuk melakukan hubungan seks (17). Refleksi, tekanan kelompok sebaya dan faktor antar generasi juga merupakan faktor yang menentukan perilaku berisiko (18). Calon bidan yang bekerja sama dengan tenaga kesehatan, sosial dan pendidikan lainnya memiliki peran penting untuk bersinergi dengan keluarga dalam mengatasi kompleksitas kehamilan remaja antar generasi.

Temuan dari penelitian ini adalah model parenting class kesehatan reproduksi remaja dapat meningkatkan pengetahuan dan sikap orangtua dalam upaya

\section{DAFTAR PUSTAKA}

1. Braeken D and Rondinelli I. Sexual and Reproductive Health Needs of Young People: Matching Needs with Systems. International Journal of Gynaecology and Obstetrics. 2012; 119(1): 60-63.

2. World Health Organization. The Sexual and Reproductive Health of Younger Adolescents: Research Issues in Developing Countries. Geneva, Switzerland:WHO; 2011: pp. 1-57.

3. Viner RM, Ozer EM, Denny S, et al. Adolescence and the Social Determinants of Health. The Lancet. 2012; 379(9826): 1641-1652.

4. Sutton MY, Lasswell SM, Lanier Y, and Miller KS. Impact of Parent-child Communication Interventions on Sex Behaviors and Cognitive Outcomes for Black/african-american And Hispanic/latino Youth: A Systematic Review, 19882012. Journal of Adolescent Health. 2014; 54(4): 369-384.

5. Kwon JA and Wickrama KAS. Linking Family Economic Pressure and Supportive Parenting to Adolescent Health Behaviors: Two Developmental Pathways Leading to Health Promoting and Health Risk Behaviors. Journal of Youth and Adolescence. 2014; 43(7): 1176-1190.

6. O'Donnell $L$ and Fuxman S. Effectiveness of a Brief Home Parenting Intervention for Reducing Early Sexual Risks among Latino Adolescents: Salud Y Éxito. Journal of School Health. 2017; 87(11): 858864.

7. Nikolajski C, Miller E, Mccauley HL, et al. Race and Reproductive Coercion: A Qualitative Assessment. Womens Health Issues. 2015; 25(3): 216-223.

8. Manu AA, Mba CJ, Asare GQ, Odoi-Agyarko K, and Asante RKO. Parent-child Communication about Sexual and Reproductive Health: Evidence from the Brong Ahafo Region, Ghana. Reproductive Health. 2015; 12(1): 1-13.

9. Legina N. Parent-Child Communication: Promoting pencegahan kehamilan remaja. Dibutuhkan komitmen dari orangtua untuk mendapatkan materi kesehatan reproduksi remaja dan cara berkomunikasi dengan remaja sebagai upaya dalam mencegah kehamilan remaja. Selain itu, perlu adanya komitmen bersama (BKKBN, institusi pendidikan melalui wadah PIKM dan pemerintah desa) agar parenting class dalam upaya pencegahan kehamilan remaja tetap berjalan secara continue, karena orangtua membutuhkan informasi tentang kesehatan remaja khususnya dalam upaya pencegahan kehamilan remaja dan berperan penting dalam membentuk perilaku anak.

\section{UCAPAN TERIMAKASIH}

Ucapan terimakasih kami sampaikan kepada BKKBN dan Sekolah Tinggi Ilmu Kesehatan AKBIDYO atas dukungannya dalam penyelesaian penelitian ini.

Sexually Health Youth. Washington, DC: Advocates for Youth; 2010; pp7-10.

10. Beckett MK, Elliott MN, Martino S, et al. Timing of Parent and Child Communication about Sexuality Relative to Children's Sexual Behaviors. Pediatrics. 2010; 125(1): 34-42.

11. Trejos-Castillo E, and Vazsonyi AT. Risky Sexual Behaviors in First and Second Generation Hispanic Immigrant Youth. Journal of Youth and Adolescence. 2009; 38(5): 719-731.

12. Aizen I and Klobas J. Fertility Intentions. Demographic Research. 2013; 29(8): 203-232.

13. Trejos-castillo E, Treviño-schafer N, Brice L, and Mcpherson K. Teen Pregnancy and Sexually Transmitted Infections in Youth: A Community Prevention Evidence- Based Program in Texas, USA. Revista CES Psicología. 2011; 5(1): 25-38.

14. Widman L, Choukas-Bradley S, Noar SM, Nesi J, and Garrett K. Parent-Adolescent Sexual Communication and Adolescent Safer Sex Behavior: A Meta-Analysis. Journal of the American Medical Association Pediatrics. 2016; 170(1): 52-61.

15. Caruthers AS, Van Ryzin MJ, and Dishion TJ. Preventing High-Risk Sexual Behavior in Early Adulthood with Family Interventions in Adolescence: Outcomes and Developmental Processes. Prevention Science. 2014; 15(1): 59-69.

16. Morawska A, Walsh A, Grabski M, and Fletcher R. Parental Confidence and Preferences for Communicating with their Child about Sexuality. Sex Education. 2015; 15(3): 235-248.

17. Sneed CD, Tan HP, and Meyer JC. The Influence of Parental Communication and Perception of Peers on Adolescent Sexual Behavior. Journal of Health Communication. 2015; 20(8): 888-892.

18. Whitehead E. Understanding the Association between Teenage Pregnancy and Inter-generational Factors: A Comparative and Analytical Study. Midwifery. 2009; 25(2): 147-154 